\title{
Effect of Continuous Therapeutic Ultrasound and Stretching Exercise on Calf Muscle Cramp during Pregnancy
}

\author{
PETER B. MELAD, M.Sc.*; HALA M. HANAFY, Ph.D.**; MARWA A.E. MOHAMED, Ph.D.** and \\ AMIR A. GBR, M.D.*** \\ The Department of Physical Therapy, El-Sahel Teaching Hospital* , The Department of Physical Therapy, Women Health, \\ Faculty of Physical Therapy** and The Department of Obstetrics \& Gynecology, Faculty of Medicine***, Cairo University
}

\begin{abstract}
Background: This study aimed to investigate the effect of continuous ultrasound and stretching exercise on calf muscle cramp during pregnancy.

Design: Randomized clinical trial.

Subjects and Methods: Thirty volunteers' pregnant women suffering from calf muscle cramp assigned into two equal groups. Their ages were ranged from 20-35 years.

This study conducted at Nahea Family Medical Center, Giza, Egypt.

Intervention: Group (A) received continuous ultrasound with frequency $1 \mathrm{MHz}$, intensity $1.5 \mathrm{w} / \mathrm{cm}^{2}, 5$ minutes in each session and stretching exercise of calf muscle by 15 seconds of passive stretch to the calf muscle followed by 30 seconds of rest with repetition 6 times per session with instructions about dealing with cramp by self slow sustained stretch. Group (B): Received the same instructions about dealing with cramp with self slow sustained stretch for calf muscle. Treatment sessions were applied 3 times/week for 4 weeks for two groups.
\end{abstract}

Outcome Measures: Cramp questionnaire with description of muscle cramps with visual analogue scale was used to assess severity of pain. Evaluation was performed before and after treatment.

Results: There was no significant difference between control and study group in pre and post treatment in exaggerating factors, localization, and duration of cramp. There was significant difference between study group and control group in frequency, time of having cramp and quality of life deterioration.

Conclusion: Stretching exercise is effective in treating calf cramp during pregnancy and adding ultrasound to stretch is making significant difference than stretching alone in decreasing the frequency of cramps, time of having cramps and in decreasing the deterioration of life quality.

Key Words: US - Stretching exercise - Calf-Cramp Pregnancy.

Correspondence to: Dr. Peter B. Melad, The Department of Physical Therapy, El-Sahel Teaching Hospital

\section{Introduction}

LEG cramps in pregnancy are a common problem characterized by sudden, intense, painful, and involuntary contractions of the leg muscles in pregnant women not experiencing any leg cramps secondary to other disease (e.g. amyotrophic lateral sclerosis, hypothyroidism), receiving medication (e.g. diuretics), undergoing hemodialysis or restless legs syndrome [1]

Up to thirty to fifty percent of pregnant women suffer from leg cramps, especially in the third trimester. Almost two-thirds of these women experience leg cramps twice per week and they can occur at any time, particularly at night [2]

In most cases, leg cramps only last for seconds, but in severe cases, leg cramps in pregnancy will last for minutes with severe pain, which can affect daily activities, limit exercise and performance, cause sleep disturbance and reduce the quality of life [3].

Leg cramps have been included in sleep-related movement disorders. For pregnant women, leg cramps overnight can cause sleep disorders such as sleep loss and insomnia, which may affect the outcome of labor including the length of labor and mode of delivery [4]

Leg cramps in pregnancy are also related to depression which can increase placental corticotrophin releasing factor and initiate uterine contractions and cervical ripening, and eventually may cause labor difficulty, fetus hypoxia and increased risks of neonatal asphyxia and postpartum hemorrhage [5]. 
Muscle cramps usually occur with a rapid increase of loading on an already shortened muscle. Disturbances in fluid and electrolyte balance make muscles more susceptible to cramping. The same applies to energy losses after exhaustive exercising. Muscles kept in a shortened state for prolonged periods of time are more likely to cramp without previous loading [6].

Unfortunately, the etiology and the precise mechanism of leg cramps in pregnancy are still unclear. To date, there is no guideline to clarify the diagnostic criteria of leg cramps in pregnancy [1]

A number of interventions are available for leg cramps in pregnancy. The most commonly used can be divided into two categories: Drug/electrolyte /vitamin therapies and non-drug therapies. Historically, quinine and its derivatives were the effective mainstay therapy for idiopathic muscle cramps, including leg cramps in pregnancy [7].

Because of these serious adverse effects, multiple drug regulatory agencies have banned the use of quinine for muscle cramps [8].

Non-drug treatments are described as being effective for the treatment of muscle cramps. They are commonly used in treating acute cramps and preventing cramps include muscle stretching, massage, relaxation, heat therapy and dorsiflexion of the foot [9].

Muscle stretching causes a sudden interruption of cramp induced by either voluntary contraction or electrical stimulation of the peripheral. Passive stretch of a contracting muscle effectively activates autogenic inhibitory $\mathrm{Ib}$ afferents in the tendon. However, it has been proposed that the inhibition following electrical stimulation arises from Group III tendon afferents that presynaptically inhibit the terminals of 1a stretch reflex afferents. It is thus possible that these afferents are responsible for inhibition of cramp, although little is known about their response to passive stretch [10]

Nightly stretching of the calves and hamstrings reduces the of frequency nocturnal leg cramps in older adults. Nightly stretching also lessens the pain associated with any cramps that continue to occur. Also, it is worth considering as an alternative therapy. It is easy to perform, has a very low risk of side effects, and often relieves the pain when a cramp has occurred [11].

The application of heat to muscle is commonly advocated as a mean to enhance the efficacy of stretching. Potential mechanisms by which heat could enhance the results of stretching relate either to increased tissue temperature, increased blood flow, or reduced muscle activity (i.e. relaxation). Increased muscle blood flow in response to heating has been postulated to reduce muscle spasm by improving local circulation and clearance of waste products [12].

This proposed ability of ultrasound applications to raise joint tissue temperatures by generating a micro-massage effect in muscle and connective tissues is believed to reduce muscle spasm and stimulate healing, including increases in cell membrane permeability, calcium transport across the cell membrane, removal of proteins and blood from interstitial spaces, nutrient exchange, and phagocytic activity of macrophages. Its application may also help to elevate pain thresholds, increase collagen extensibility, tissue metabolic rates, blood flow and healing [13] .

\section{Patients and Methods}

Design: The design of the study was randomized control clinical trial, with pre-post measurements.

Participant: The current study was conducted at Gynecology and Obstetric Unit in Nahea Family Medicine Center from Feb.-Dec. 2016, patient were referred from the Outpatient Gynecology and Obstetric Physician after being examined, whom was blinded about the treatment groups, to exclude patient with exclusion criteria (a copy of exclusion criteria were sent to gynecology and obstetric clinic). Based on power analysis, the sample size was 100 patients but not all the patient completes the study. Their ages were ranged from 20 to 35 years old. Subjects who participated in this study had the following criteria: Patient had suffered from cramps during pregnancy and it was not secondary other disease (e.g. amyotrophic lateral sclerosis, hypothyroidism), receiving medication (e.g. diuretics), undergoing hemodialysis or restless legs syndrome. Subjects had been excluded if they have any of the following:

1- Participants who had skin abnormalities (skin malignancy in the treated area or burned).

2- History of previous back surgery.

3- Neuromuscular diseases like multiple sclerosis.

4- Sensory disturbances.

5- Evidence of previous vertebral fractures or major spinal structural abnormality, spondylolisthesis or spinal stenosis.

6- Systemic disease of musculoskeletal system. 
7- Viscerogenic cause of back pain.

8- Eclampsia or pre-eclampsia.

After selection through consultation with a gynecology and obstetric physician, the patients provided their written consent and were given an opportunity to ask any questions regarding the procedure. The study program had been approved by the ethical committee of general organization of ministry of health. Sealed envelope used for allocation of patient over the 2 groups by other clinician who was blinded about the study, then pre-treatment measurement were applied by the main researcher who was blinded about to which group patient was allocated.

Intervention: Study was performed in 16 months, treatment program given in 12 sessions ( 3 sessions per week) for the 2 groups. The patients were examined and data recorded in a pre-prepared card. Many patients ( 70 patients) didn't continue the full program of the study while 30 patients continue the full program of the study.

Patients were divided into two equal groups (A and $B)$. Group A: $(n=15)$ received ultrasound followed by stretching exercise for 3 times per week for four weeks with instructions and advice about dealing with muscle cramp with self slow sustained stretch for calf muscle. Group B: $(n=15)$ received instructions and advice about dealing with muscle cramp with self slow sustained stretch for calf muscle. Treatment had been carried out in Gynecology and Obstetric Unit in Nahea Family medicine center. The program of the study was given for two groups three sessions per week for four weeks.

Group A: Received ultrasound at frequency 1 $\mathrm{MHz}$, continuous mode of application, intensity $1.5 \mathrm{w} / \mathrm{cm}, 5$ minutes in each session followed by 15 seconds of passive stretch to the calf muscle followed by 30 seconds of rest and this exercise was repeated 6 times per session with total time of session 10 minutes, 12 session for a month, 3 session/week. And they are all was instructed to participate self slow sustained stretch for the calf muscle when the cramp occur.

Group B: The participants in Group (B) did not receive the ultrasound or the stretching exercise but they received the same instructions and advice about dealing with muscle cramp with self slow sustained stretch for calf muscle.

\section{Outcome measures:}

The measurements used in this study were visual Cramp questionnaire to capture description of muscle cramps (onset, precipitating events, frequency, duration, relief, and localization) and severity of pain by visual analogue scale for pain (Wong-Baker FACES Pain Rating Scale) was used before starting treatment session and at the end of the program to detect severity and frequency of calf cramp $[\mathbf{1 4 , 1 5}]$

\section{Data analysis:}

SPSS program was used to analyze the data. Statistics of this study was performed by a lecturer of biostatistics at statistics institute at Cairo University and he was masked about the patients groups. Results are expressed as mean \pm standard deviation, number (\%), median, minimum and maximum. Comparison between different variables in the two groups was performed using unpaired $t$-test or Mann Whitney test whenever it was appropriate. Pair wise group comparison (pre versus post) was performed using Wilcoxon Signed Ranks test. Statistical Package for Social Sciences (SPSS) computer program (Version 19 windows) was used for data analysis. $p$-value $\leq 0.05$ was considered significant.

\section{Results}

Consort flow chart of the patients was made:

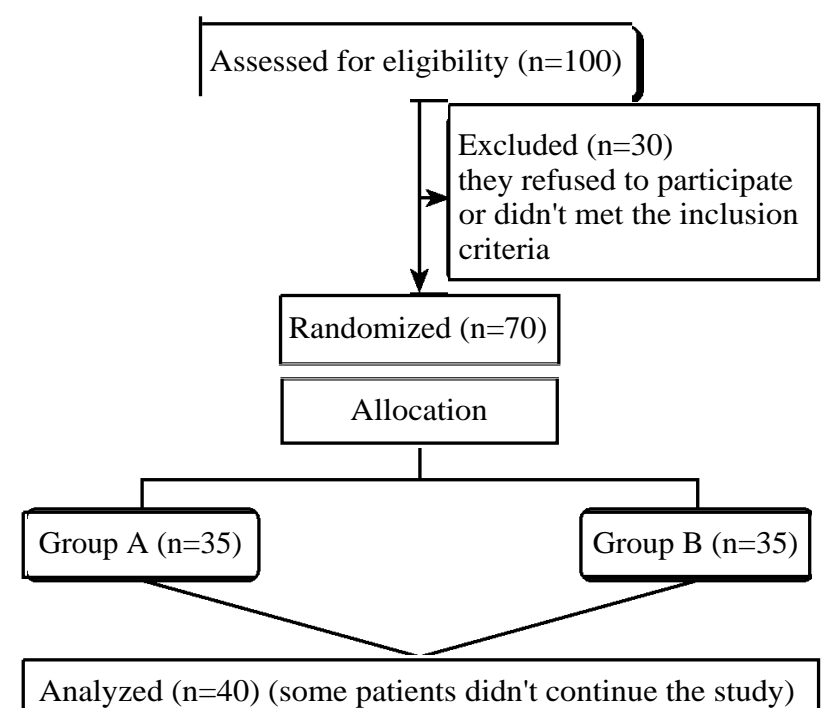

Analyzed ( $\mathrm{n}=40)$ (some patients didn't continue the study)

Group A ( $\mathrm{n}=15)$

Group B ( $\mathrm{n}=15)$

Thirty pregnant women, with cramp due to pregnancy and it was not secondary other disease (e.g. amyotrophic lateral sclerosis, hypothyroidism), receiving medication (e.g. diuretics), undergoing hemodialysis or restless legs syndrome .assigned into 2 equal groups. Group A $(n=15)$ their mean age was $(23.20 \pm 4.35)$ years, Group B $(n=15)$ their 
mean age was $(24.53 \pm 3.54)$ years with $t$-valu=0.921 and $p$-value $=0.365$, patient physical characteristics are represented in (Table 1). Patient in the study didn't receive physical therapy sessions before. Patient's jobs were varied; most of female patients were housewives while others were workers.

There was no significant difference between control and study group in pre and post treatment in questions 7 (factors exaggerate cramp) as seen in (Table 8).

There was no significant difference in control group in questions in post treatment results according to pre results in questions 2,7 and eight (frequency of cramps), (factors aggravate cramp) and (quality of life deterioration) (Tables 3,8,9).

There was significant difference in control group in post treatment results according to pre results in questions $3,4,5$ and 6 (severity of cramp), (localization of cramp), (duration of cramp) and (time of cramp) (Tables 4-7).

There was significant difference in study group in post treatment results according to pre results in questions $2,3,4,5,6,8$. (Frequency of cramp), (severity of cramp), (localization of cramp), (duration of cramp), (time of cramp) and (quality of life deterioration) (Tables 3-6,9).

There was significant difference between study group and control group in questions 2,8 (frequency of cramp) and (quality of life deterioration) (Tables $3,9)$.

Table (1): Physical characteristics of the two studied groups.

\begin{tabular}{lcccc}
\hline & $\begin{array}{c}\text { Control group } \\
(\mathrm{n}=15)\end{array}$ & $\begin{array}{c}\text { Study group } \\
(\mathrm{n}=15)\end{array}$ & $\begin{array}{c}t \text { - } \\
\text { value }\end{array}$ & $\begin{array}{c}p \text { - } \\
\text { value }\end{array}$ \\
\hline Age (yrs. $)$ & $24.53 \pm 3.54$ & $23.20 \pm 4.35$ & 0.921 & 0.365 \\
Weight $(\mathrm{kg})$. & $77.87 \pm 8.84$ & $78.47 \pm 6.82$ & -0.208 & 0.837 \\
Height $(\mathrm{cm})$ & $159.20 \pm 6.64$ & $159.27 \pm 5.39$ & -0.030 & 0.976 \\
BMI $\left(\mathrm{kg} / \mathrm{m}^{2}\right)$ & $30.69 \pm 3.16$ & $30.92 \pm 3.00$ & -0.030 & 0.976
\end{tabular}

Data are expressed as mean \pm SD

$\mathrm{NS}=p>0.05=$ Not Significant.

Table (2): Inter-and intra-group comparison between median values of frequency of these experienced muscle cramps in the two studied groups.

\begin{tabular}{lllcc}
\hline & $\begin{array}{c}\text { Control group } \\
(\mathrm{n}=15)\end{array}$ & $\begin{array}{c}\text { Study group } \\
(\mathrm{n}=15)\end{array}$ & $\begin{array}{c}\mathrm{Z}- \\
\text { value }\end{array}$ & $\begin{array}{c}p \text { - } \\
\text { value }\end{array}$ \\
\hline Pre & $2.0(1.0-2.0)$ & $2.0(1.0-2.0)$ & -0.362 & $0.717(\mathrm{NS})$ \\
Post & $2.0(1.0-2.0)$ & $2.0(1.0-3.0)$ & -1.871 & $0.061(\mathrm{NS})$ \\
Z-value & -1.414 & -2.646 & & \\
$p$-value & $0.157(\mathrm{NS})$ & $0.008(\mathrm{~S})$ & & \\
\hline
\end{tabular}

Table (3): Inter-and intra-group comparison between median values of extent of pain (VAS) in the two studied groups.

\begin{tabular}{lcccc}
\hline & $\begin{array}{c}\text { Control group } \\
(\mathrm{n}=15)\end{array}$ & $\begin{array}{c}\text { Study group } \\
(\mathrm{n}=15)\end{array}$ & $\begin{array}{c}\mathrm{Z}- \\
\text { value }\end{array}$ & $\begin{array}{c}p \text { - } \\
\text { value }\end{array}$ \\
\hline Pre & $3.0(2.0-5.0)$ & $4.0(1.0-5.0)$ & -0.770 & $0.441(\mathrm{NS})$ \\
Post & $3.0(1.0-4.0)$ & $2.0(0.0-4.0)$ & -0.733 & $0.464(\mathrm{NS})$ \\
Z-value & -3.051 & -2.745 & & \\
$p$-value & $0.002(\mathrm{~S})$ & $0.006(\mathrm{~S})$ & & \\
\hline
\end{tabular}

Table (4): Inter-and intra-group comparison between median values of localization of cramps in the two studied groups.

\begin{tabular}{lcccc}
\hline & $\begin{array}{c}\text { Control group } \\
(\mathrm{n}=15)\end{array}$ & $\begin{array}{c}\text { Study group } \\
(\mathrm{n}=15)\end{array}$ & $\begin{array}{c}\mathrm{Z}- \\
\text { value }\end{array}$ & $\begin{array}{c}p- \\
\text { value }\end{array}$ \\
\hline Pre & $1.0(1.0-2.0)$ & $1.0(1.0-2.0)$ & -0.733 & $0.464(\mathrm{NS})$ \\
Post & $1.0(1.0-2.0)$ & $1.0(1.0-1.0)$ & -1.439 & $0.150(\mathrm{NS})$ \\
Z-value & -2.236 & -2.236 & & \\
$p$-value & $0.025(\mathrm{~S})$ & $0.025(\mathrm{~S})$ & & \\
\hline
\end{tabular}

Table (5): Inter-and intra-group comparison between median values of the time of day when having cramps in the two studied groups.

\begin{tabular}{lclcl}
\hline & $\begin{array}{c}\text { Control group } \\
(\mathrm{n}=15)\end{array}$ & $\begin{array}{c}\text { Study group } \\
(\mathrm{n}=15)\end{array}$ & $\begin{array}{c}\mathrm{Z}- \\
\text { value }\end{array}$ & $\begin{array}{c}p \text { - } \\
\text { value }\end{array}$ \\
\hline Pre & $2.0(1.0-3.0)$ & $2.0(1.0-3.0)$ & -1.221 & $0.222(\mathrm{NS})$ \\
Post & $2.0(1.0-3.0)$ & $2.0(1.0-2.0)$ & -2.489 & $0.013(\mathrm{~S})$ \\
Z-value & -1.000 & -2.000 & & \\
$p$-value & $0.317(\mathrm{NS})$ & $0.046(\mathrm{~S})$ & & \\
\hline
\end{tabular}

Table (6): Inter-and intra-group comparison between median values of how long do cramps last in the two studied groups.

\begin{tabular}{lcccc}
\hline & $\begin{array}{c}\text { Control group } \\
(\mathrm{n}=15)\end{array}$ & $\begin{array}{c}\text { Study group } \\
(\mathrm{n}=15)\end{array}$ & $\begin{array}{c}\mathrm{Z}- \\
\text { value }\end{array}$ & $\begin{array}{c}p- \\
\text { value }\end{array}$ \\
\hline Pre & $2.0(1.0-2.0)$ & $2.0(1.0-2.0)$ & -0.898 & $0.369(\mathrm{NS})$ \\
Post & $2.0(1.0-2.0)$ & $1.0(1.0-2.0)$ & -1.466 & $0.143(\mathrm{NS})$ \\
Z-value & -1.732 & -3.000 & & \\
$p$-value & $0.083(\mathrm{NS})$ & $0.003(\mathrm{~S})$ & & \\
\hline
\end{tabular}

Table (7): Inter-and intra-group comparison between median values of their aggravation in the two studied groups.

\begin{tabular}{lcccc}
\hline & $\begin{array}{c}\text { Control group } \\
(\mathrm{n}=15)\end{array}$ & $\begin{array}{c}\text { Study group } \\
(\mathrm{n}=15)\end{array}$ & $\begin{array}{c}\mathrm{Z}- \\
\text { value }\end{array}$ & $\begin{array}{c}p \text { - } \\
\text { value }\end{array}$ \\
\hline Pre & $4.0(1.0-7.0)$ & $5.0(1.0-9.0)$ & -0.998 & $0.318(\mathrm{NS})$ \\
Post & $4.0(1.0-5.0)$ & $5.0(2.0-6.0)$ & -1.058 & $0.290(\mathrm{NS})$ \\
Z-value & -0.707 & -0.259 & & \\
$p$-value & $0.480(\mathrm{NS})$ & $0.796(\mathrm{NS})$ & & \\
\hline
\end{tabular}

Data are expressed as median (minimum-maximum).

$\mathrm{NS}=p>0.05=$ Not Significant. 
Table (8): Inter-and intra-group comparison between median values of quality of life deterioration because of muscle cramp in the two studied groups.

\begin{tabular}{lllcc}
\hline & $\begin{array}{c}\text { Control group } \\
(\mathrm{n}=15)\end{array}$ & $\begin{array}{c}\text { Study group } \\
(\mathrm{n}=15)\end{array}$ & $\begin{array}{c}\mathrm{Z} \text { - } \\
\text { value }\end{array}$ & $\begin{array}{c}p \text { - } \\
\text { value }\end{array}$ \\
\hline Pre & $2.0(1.0-3.0)$ & $2.0(1.0-3.0)$ & -1.147 & $0.251(\mathrm{NS})$ \\
Post & $2.0(1.0-3.0)$ & $3.0(2.0-3.0)$ & -1.114 & $0.265(\mathrm{NS})$ \\
Z-value & -1.732 & -2.919 & & \\
$p$-value & $0.083(\mathrm{NS})$ & $0.004(\mathrm{~S})$ & & \\
\hline
\end{tabular}

Data are expressed as median (minimum-maximum).

$\mathrm{NS}=p>0.05=$ Not significant. $\quad \mathrm{S}=p<0.05=$ Significant.

\section{Discussion}

Lengthening or stretching the cramping muscle and activating the antagonist muscles helps to stop most cramps based on the observation that stretching treats acute cramps and that experimentally induced cramps do not occur in lengthened muscles, stretching was also tried as a preventive strategy. This simple, low-risk treatment should be suggested first in all patients with cramps [16]

Stretching of the calf and hamstring muscles significantly reduced the frequency and severity of nocturnal leg cramps in older people. Stretching exercises were effective in preventing the occurrence of nocturnal leg cramps [11].

Muscle stretching was capable of sharply interrupting cramps induced both by voluntary contraction and by high-frequency stimulation of peripheral nerve. Muscle lengthening interferes with the development and course of the cramps [17].

Muscle stretching causes a sudden interruption of cramp induced by either voluntary contraction or electrical stimulation of the peripheral. Passive stretch of a contracting muscle effectively activates autogenic inhibitory Ib afferents in the tendon. However, it has been proposed that the inhibition following electrical stimulation arises from Group III tendon afferents that presynaptically inhibit the terminals of 1a stretch reflex afferents. It is thus possible that these afferents are responsible for inhibition of cramp [10].

On contrary, there are studies which concluded that a stretching intervention failed to significantly relieve the intensity and frequency of nocturnal leg cramps and the results do not confirm that regular calf stretching exercises are an effective intervention in reducing the frequency or severity of nocturnal leg cramps. But one of possible weaknesses in the design of this study were the nature of the placebo exercise and the fact that patients were not blinded to the interventions [18].
For ultrasound, there are some studies who revealed the effect of ultrasound in improving pain which concluded that effects of ultrasound in the temperature range of $40^{\circ} \mathrm{C}$ to $45^{\circ} \mathrm{C}\left(104^{\circ} \mathrm{F}\right.$ to $\left.113^{\circ} \mathrm{F}\right)$ include reduced pain as a result of decreased nerve conduction velocity, increased metabolic rate, increased blood flow to assist in resolution of edema, enhanced immune system response, increased extensibility of soft tissue, an decreased viscosity of tissue fluids [19]

According to some researchers, heating tissue before stretching will lead to improved range of motion of chronic connective tissue and joint contractures. When ultrasound is used to vigorously heat tissues, the tissues become more pliable allowing the tissues to be stretched more effectively [20]

Also, it has been suggested that many of the benefits of using ultrasound (increased local blood flow, pain relief, and increased wound healing) are due to heating. Abramson et all reported that ultrasound treatments achieving a $3^{\circ} \mathrm{C}$ increase (from a baseline of $36^{\circ} \mathrm{C}$ to an increase of $39^{\circ} \mathrm{C}$ ) produced a marked increase in blood flow to the tissues. Lehmann stated that slightly lower temperature increases of $1^{\circ} \mathrm{C}$ can reduce mild inflammation and increase metabolism, and that moderate heating (an increase of $2^{\circ}$ to $3^{\circ} \mathrm{C}$ ) will decrease pain and muscle spasm. And this explains the significant improve in study group in question number two which was about the frequency of muscle cramp [21]

In the ease of joint movement secondary to the increase in collagen extensibility associated with heating may add to the patient's perception of decreased pain. Evaluation of several ultrasound studies concluded that there is also a lack of evidence from well-designed, controlled randomized studies that ultrasound is effective in pain modulation." Hashish and coworkers" demonstrated a reduction of pain secondary to placebo administration." They concluded that the massage provided by the transducer may have muted pain in the sham ultrasound group [22].

And this could explain why frequency and quality of life deterioration improved in study group even there is no significant difference between two groups.

This demonstrated that the most effective time to encourage range of motion and stretching exercises within rigid tissues is actually less than 3 minutes following ultrasound treatments that raise the temperature $>3^{\circ} \mathrm{C}$. Stretching may be performed 
at a lower temperature; however, it will not be optimal. Therefore, it is probable that many clinicians perform ineffective heat and stretch therapy and this also explains why adding ultrasound to stretch exercise failed to give significant difference between control groups pre and post treatment.

\section{Conclusion:}

The following conclusion was warranted: That stretching exercise is effective in treating calf muscle cramp during pregnancy but adding ultrasound to stretch exercise is not making significant difference than stretching exercise alone except in decreasing the frequency, time of having calf muscle cramp and in decreasing the deterioration of life quality due to muscle cramp.

\section{References}

1- ZHOU K., WEST H.M., ZHANG J., XU L. and LIW: Interventions for leg cramps in pregnancy. Cochrane Database of Systematic Reviews, Issue 8. Art. No.: CD010655, 2015.

2- SOHRABVAND F., SHARIAT M. and HAGHOLLAHI F.: Vitamin B supplementation for leg cramps during pregnancy. International Journal of Gynecology \& Obstetrics; 95 (1): 48-9, 2006.

3- ALLEN R.E. and KIRBY K.A.: Nocturnal leg cramps. American Family Physician; 86 (4): 350-5, 2012.

4- HENSLEY J.G.: Leg cramps and restless legs syndrome during pregnancy. Journal of Midwifery and Women's Health; 54 (3): 211-8, 2009.

5- DAYAN J., CREVEUIL C., HERLICOVIEZ M., HERBEL C., BARANGER E., SAVOYE C., et al.: Role of anxiety and depression in the onset of spontaneous preterm labor. American Journal of Epidemiology; 155: 293-301, 2002.

6- LEON CHAITOW: Stretching theory: Jari ylinen Stretching Therapy For sport and manual therapies. English edition: London; section 1: 1-90, 2008.

7- KATZBERG H.D., KHAN A.H. and SO Y.T.: Assessment: Symptomatic treatment for muscle cramps (an evidencebased review): Report of the therapeutics and technology assessment subcommittee of the American academy of neurology. Neurology; 74 (8): 691-6, 2010.

8- Food, Drug Administration. Quinine: Important warning. http://www.fda.gov/NewsEvents/Newsroom/Press Announcements/2006/ucm 108799.htm.

9- BLYTON F., CHUTER V., WALTER K.E.L., and BURNS J.: Non-drug therapies for lower limb muscle cramps. Cochrane Database of Systematic Reviews, Issue 1. Art. No CD008496, 2012.
10- KHAN S.I. and BURNE J.A.: Reflex inhibition of normal cramp following electrical stimulation of the muscle tendon. Journal of Neurophysiology; 3 (98): 1102-7, 2007.

11- HALLEGRAEFF J.M., VAN DER SCHANS C.P., De RULTER R. and De GREEF M.H.G.: Stretching before sleep reduces the frequency and severity of nocturnal leg cramps in older adults: A randomized trials. Journal of Physiotherapy, 58: 17-22, 2012.

12- JIRO NAKANO, CRISTIANE Y., ALEX S. and DARLENE R.: The effect of heat applied with stretch to increase range of motion. Journal of Physical Therapy in Sport; 13 (1) pp. 180-8, 2012.

13- MARKS R., GHANAGARAJA S. and GHASSEMI M. Ultrasound for osteo-arthritis of the knee', Physiotherapy; 86 (9): 452-63, 2000.

14- CHATRATH H., LIANGPUNSAKUL S., GHABRIL M., OTTE J., CHALASANI N. and VUPPALANCHI R. Prevalence and Morbidity Associated with Muscle Cramps in Patients with Cirrhosis. The American Journal of Medicine, 125 (10): 1019-1025, 2012.

15- SHIVANG S. MEHTA and MICHAEL B. FALLON.: Muscle Cramps in Liver Disease. Clinical. Volume 11, Issue 11, pp. 1385-91, 2013

16- TIMOTHY M. MILLER and ROBERT B. LAYZER: "Muscle Cramps", Muscle \& Nerve; 32: pp. 431-42, 2005.

17-MARCO ALESSANDRO MINETTO, ALE S HOLOBAR, ALBERTO BOTTER, ROBERTA RAVENNI and DARIO FARINA: Mechanisms of cramp contractions: Peripheral or central generation; Journal of Physic Therapy; 589 (23): pp. 5759-73, 2011.

18- COPPIN R.J., WICKE D.M. and LITTLE P.S.: Managing nocturnal leg cramps-calf-stretching exercises and cessation of quinine treatment: A factorial randomized controlled trial. British Journal of General Practice; 55: 186-91, 2005.

19- BARBARA J. BEHRENS, ETHNE L. NUSSBAUM and PETER C. PANUS.: Theory and Practice: Therapeutic Ultrasound and Phonophoresis. In Barbara J. Behernes and Holly Beinert: Physical Agents. Third Edition United States; Chapter, 5: Pp. 90-126, 2014.

20- MAY S.F. LEUNG, and GLADYS L.Y. CHEING: Effects of Deep and superficial heating in the Management of Frozen Shoulder, Journal of Rehabilitation Medicine, (40): 145-50, 2008.

21- GARRETT, CANDI L., DAVID O. DRAPER and KENNETH L. KNIGHT: Heat distribution in the lower leg from pulsed short-wave diathermy and ultrasound treatments. Journal of Athletic Training; (35): 50-5, 2000.

22- YUKA SAEKI: Effect of local application of cold or heat for relief of pricking pain; Nursing and Health Sciences; (4): 97-105, 2002. 


\section{تآثير الموجات فوق الصوتية العلاجية المستمرة

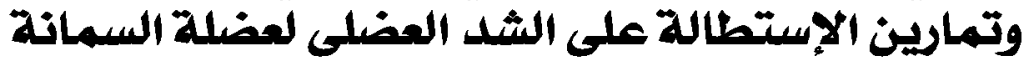 آثناء الحمل الهل العناء}

تهدف هذه الرسالة إلى تقييم تآثير الموجات فوق الصوتية العلاجية المستمرة وتمارين الإستطالة على الثد العضلى لعضلة السمانة آثناء

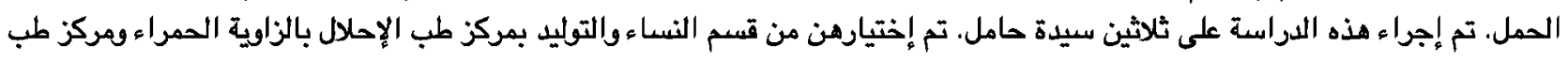

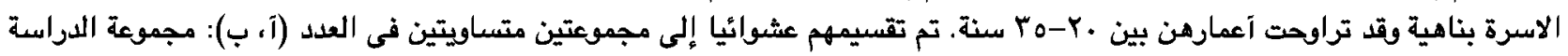

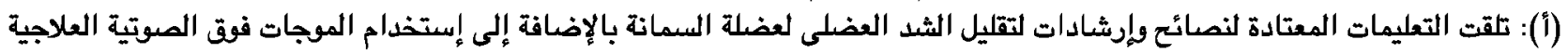

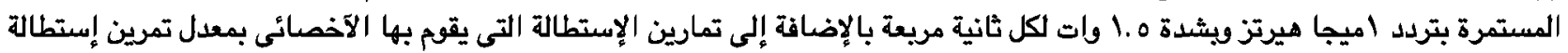

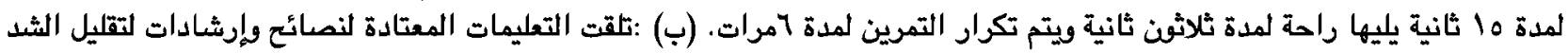

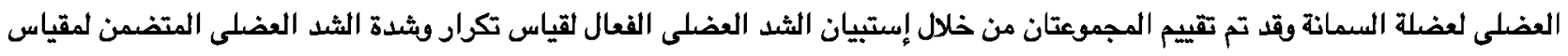

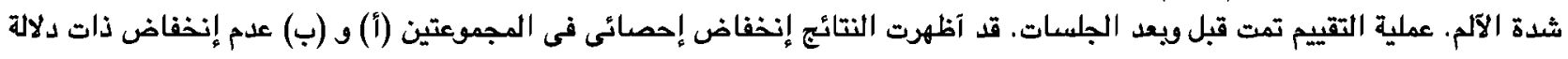

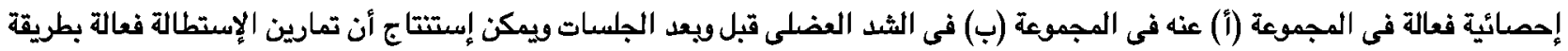

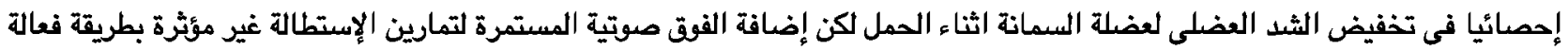

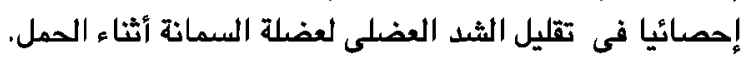
الكلمات الدالة: الموجات فوق صوتية - تمارين الإستطالة - الشد العضلى لعضلة السمانة - العمل. 